\title{
A NEWLY ACQUIRED WILLIAM COBBETT LETTER
}

\author{
BY JOHN W. OSBORNE \\ Dr. Osborne is a member of the University College Department \\ of History
}

Kensington, 21. Feb. I 828

To Sir Thomas Beevor, Baronet.

My Dear Sir,

I shall be very much obliged to you for the use of Spelman, and I beg you to be good as to send it to Fleet Street. Is it gout that has confined you? Be it what it may, I hope that it will not visit you again.

Now, indeed, the fellows are in a mess. They are now explaining every thing, except the real cause of their embarrassments; and this they will not whisper even to themselves. The state of the country now alarms them, and this because the people have betaken themselves to a species of hostility which the fellows cannot meet by either the bayonet or the dungeon. They were not prepared for this result of their taxation and tyranny; and they are, therefore, fairly nonplussed.

Their Finance Committee will be a farce, unless they propose a Bank-Restriction, which I think they will; and then we have the Grand Feast of the Gridiron, and two prices at no great distance. I hear that Western cries me up to the skies, and says that everybody ought to read me. What a coward, then! Whether, however, he speaks out or not, he must lose his estate, if my advice be not followed.

I hope that your lady and your children are all well, and I remain Your sincerely grateful and most obedient servant, Wm. Cobbett. 
HE above letter is an interesting addition to the Rutgers Library's William Cobbett collection. One of the greatest 1 political journalists of all time and an outspoken critic of English government policy, Cobbett was addressing an ally in the cause of drastic financial reform. It is clear that Cobbett could not compare with Horace Walpole in the art of writing letters, for he was too engaged politically to permit himself the luxury of ironic detachment. Also, unlike the Squire of Strawberry Hill, Cobbett had a marvelous vehicle for registering his thoughts in his weekly Political Register. Yet his letters are characteristically to the point. Although seldom supplying information of a startling kind they do provide an added dimension for understanding the thought of a man with a mind that, while it was convinced of certain truths, was still remarkably nimble.

This letter was written at a time of government change. Following the death in August I 827 of the able Prime Minister George Canning, leadership in parliament fell into the hands of Lord Goderich, an incompetent. In January I 828 Goderich was replaced as Prime Minister by a military hero but inexperienced politician, the Duke of Wellington. England thus had three different chief ministers within six months while "the fellows" (members of parliament) were, in Cobbett's eyes, shaken by the disastrous consequences of their own financial policies. To read the letter one would think that England faced revolution; actually, the state of the country (as opposed to parliament) was torpid. His message reveals that Cobbett apparently believed what he was writing at the time in the Political Register and considered that the Tory government would founder on the financial issue.

This is the point of the letter and it requires some clarification. As early as I 804, Cobbett had come to believe that the major domestic danger facing the country was the excessive number of banknotes which had resulted from an enormous increase in expenditure during. the French wars. Seven years earlier the government had suspended specie payment by the bank of England and not until I 819 was a return to gold coin permitted. Cobbett, to whom the increasing national debt and paper money were moral issues, did not want a debt which had been contracted in paper paid off in gold. In 18 I 9 he 
made his "gridiron prediction" in which he humorously volunteered to be tied to a gridiron and broiled alive over a fire if the government could accomplish its purpose without bankrupting the country. A great increase in trade during the I 820's enabled gold payment to be gradually reintroduced, although the agricultural classes were hurt by this deflation.

During these years Cobbett tried to persuade the dominant group in parliament, the landowners, that their interest lay in repudiation of the national debt. Individuals such as Sir Thomas Beevor agreed, but the majority, with financial, social and often family connections among commercial groups did not. They hoped to ride out the storm by getting high prices for their produce. One man who hedged on the subject was Charles (Squire) Western, a defender of agrarian interests in the House of Commons. By I 828 Cobbett was clearly proven wrong but he never admitted this and the front page of every Political Register flaunted a picture of a gridiron as a reminder to his enemies of their ruin which he believed to be imminent. No doubt he hoped that the rapid turnover of Prime Ministers would help to hasten the long-awaited demise of the government in power, or at least a return to restriction of specie payment. The "Grand Feast of the Gridiron" would be his vindication. Always sanguine in print, this letter also helps to prove that Cobbett could deceive himself as well as others when he wrote about complicated financial matters. ${ }^{1}$

1 These financial questions are discussed in detail in chapter eight of my William Cobbett: His Thought and His Times (New Brunswick, 1966). "Spelman" was probably Sir Henry Spelman (1564?-164I), an antiquary whose book on old English language would have been of interest to Cobbett. 